\title{
Peningkatan Prestasi Belajar Bahasa Jawa Melalui Jigsaw Pada Siswa Kelas VIII
}

\author{
Tumiyem \\ SMP Negeri 2 Sukoharjo \\ dratumiyem@yahoo.com
}

\begin{abstract}
ABSTRAK
Tujuan penelitian tindakan kelas ini adalah untuk meningkatkan prestasi belajar bahasa Jawa siswa melalui model pembelajaran kooperatif tipe jigsaw pada siswa kelas VIII I semester I SMP Negeri 2 Sukoharjo tahun pelajaran 2016/ 2017. Penelitian ini dilaksanakan pada bulan Juli sampai November 2016 di SMP Negeri 2 Sukoharjo. Subyek penelitian ini adalah siswa kelas VIII I sebanyak 32 siswa. Penelitian Tindakan Kelas ini dilakukan dalam dua siklus. Teknik pengumpulan data menggunakan teknik dokumentasi, observasi, dan tes tertulis. Alat pengumpulan data berupa lembar pengamatan, butir soal tes, dan dokumen daftar nilai. Analisis data menggunakan analisis deskriptif komparatif yang dilanjutkan refleksi. Setiap siklus terdiri dari empat langkah, yaitu: (1) Perencanaan, (2) Pelaksanaan Tindakan, (3) pengamatan, dan (4) Refleksi. Hasil penelitian menunjukkan adanya peningkatan prestasi belajar bahasa Jawa siswa, nilai ratarata prestasi belajar bahasa Jawa siswa mengalami peningkatan yaitu sebelum tindakan sebesar 68,9, pada siklus I sebesar 73,6 dan pada siklus II sebesar 81,6. Selain itu, persentase ketuntasan belajar siswa juga meningkat, yaitu sebelum tindakan sebesar 37,5\%, siklus I sebesar $62,5 \%$ dan siklus II sebesar 93,75\%. Sehingga dapat disimpulkan bahwa "Penggunaan jigsaw dapat meningkatkan prestasi belajar bahasa Jawa siswa kelas VIII I semester I SMP Negeri 2 Sukoharjo tahun pelajaran 2016/ 2017 ".
\end{abstract}

Kata kunci: Prestasi Belajar Bahasa Jawa, Model Pembelajaran Kooperatif Tipe Jigsaw

\begin{abstract}
The purpose of this classroom action research is to improve students' learning achievement of Javanese language through cooperative learning model of jigsaw type in grade VIII I students of semester I of SMP Negeri 2 Sukoharjo in the 2016/ 2017 school year. This research was conducted from January to June 2016 in SMP Negeri 2 Sukoharjo. The subjects of this study were students of class VIII I as many as 32 students. This research is a Classroom Action Research conducted in two cycles. Data collection techniques used documentation, observation, and written tests. Data collection tools are observation sheets, test items, and value list documents. Data analysis using comparative descriptive analysis followed by reflection on each cycle consists of four steps, namely: (1) Planning, (2) Action Implementation, (3) observation, and (4) reflection.

The results of this study indicate an increase in learning achievement of Javanese students. This can be seen from the average score of learning achievement of Javanese students also
\end{abstract}


experienced an increase before the action of 68,9, in the first cycle of 73,6 and on the second cycle of 81,6 . In addition, the percentage of students' learning mastery, example before the action of $37,5 \%$, in the first cycle of $62,5 \%$ and in the second cycle of $93,75 \%$. So it can be concluded that "The use of cooperative learning model of jigsaw type can improve the learning achievement of Javanese language students of class VIII I semester I SMP Negeri 2 Sukoharjo 2016/ 2017 academic year".

Keywords: Learning Achievement of Java Language, Cooperative Learning Model of Jigsaw Type

\section{PENDAHULUAN}

Berbagai upaya telah dilakukan untuk meningkatkan mutu pendidikan, khususnya pendidikan bahasa Jawa oleh berbagai pihak yang peduli kepada mata pelajaran bahasa Jawa di sekolah. Namun hasil belajar yang dicapai belum sesuai seperti yang diharapkan.

Soedjadi (2001) berpendapat bahwa penyebab kesulitan dapat bersumber dari dalam diri siswa juga dari luar diri siswa, misalnya cara penyajian materi pelajaran atau suasana pembelajaran yang dilaksanakan. Lebih lanjut dikatakan bahwa betapapun tepat dan baiknya bahan ajar bahasa Jawa yang ditetapkan belumlah menjamin akan tercapainya tujuan pendidikan bahasa Jawa yang diinginkan. Salah satu faktor penting untuk mencapai tujuan pendidikan adalah proses belajar yang dilaksanakan.

Hambatan lain adalah, bahwa guru masih melaksanakan penilaian yang bersifat teoretis (berupa pengetahuan dan pemahaman konsep) saja. Jadi pada pembelajaran bahasa Jawa, guru lebih cenderung mengevaluasi hal-hal yang berkaitan dengan teori.

Dikaitkan dengan bidang studi bahasa Jawa, pada umumnya siswa beranggapan bahwa bahasa Jawa memerlukan pemahaman yang sangat sulit. Asumsi yang demikian ini dapat merugikan siswa yang kurang senang terhadap pelajaran bahasa Jawa. Siswa akan merasa pesimis terhadap pelajaran bahasa Jawa sehingga menyebabkan siswa tidak mempunyai motivasi untuk mempelajarinya. Dengan tidak mempelajarinya justru akan semakin sulit, sehingga berakibat pada prestasi yang tidak memuaskan (nilai kurang baik). Sebaliknya jika siswa mempunyai motivasi belajar tinggi, siswa akan memiliki tingkat pemahaman yang 
lebih tinggi dan dapat mencapai tujuan belajar pendidikan bahasa Jawa. Motivasi belajar siswa terhadap bahasa Jawa dimungkinkan dapat meningkatkan prestasi belajar siswa dalam pelajaran bahasa Jawa. Dalam proses belajar mengajar bahasa Jawa di SMP sering dijumpai beberapa siswa dengan prestasi belajar bahasa Jawa rendah, bila disimak lewat prestasi nilai harian. Nilai kurang yang dicapai oleh siswa berarti belum mencapai prestasi seperti yang diharapkan. Hal ini mungkin dikarenakan anak kurang tertarik pada mata pelajaran bahasa Jawa dan tidak adanya semangat untuk mempelajarinya. Oleh karena itu seorang guru bahasa Jawa haruslah pandai-pandai memilih metode yang tepat agar siswa mudah memahami materi yang diajarkan oleh guru.

Berkaitan dengan hal tersebut, permasalahan yang sama terjadi di SMP Negeri 2 Sukoharjo dimana kegiatan pembelajaran hanya berpusat pada guru sehingga sebagian besar siswanya menjadi pasif dan tidak konsentrasi. Berdasarkan hasil ulangan mata pelajaran bahasa jawa materi Membaca Paragraf Sederhana Berhuruf Jawa pada siswa kelas VIII I SMP Negeri 2 Sukoharjo, didapatkan 12 siswa $(37,5 \%)$ yang tuntas atau melebihi KKM dari jumlah 32 siswa. KKM bahasa Jawa di SMP Negeri 2 Sukoharjo adalah 75.

Salah satu model pembelajaran yang dapat dikembangkan dalam pengajaran agar anak berpartisipasi aktif adalah metode cooperative learning tipe jigsaw. Metode pembelajaran cooperative learning tipe jigsaw merupakan suatu tipe pembelajaran kooperatif yang terdiri dari beberapa anggota dalam satu kelompok yang bertanggung jawab atas penguasaan bagian materi belajar dan mampu mengajarkan materi tersebut kepada anggota lain dalam kelompoknya. Model cooperative learning tipe jigsaw merupakan model pembelajaran kooperatif dimana siswa belajar dalam kelompok kecil yang terdiri dari 4-6 orang secara heterogen dan bekerja sama saling ketergantungan yang positif dan bertanggung jawab atas ketuntasan bagian materi pelajaran yang harus dipelajari dan menyampaikan materi tersebut kepada anggota kelompok yang lain.

Jigsaw pertama kali dikembangkan dan diujicobakan oleh Elliot Aronson dan teman-teman di Universitas Texas, dan kemudian diadaptasi oleh Slavin dan temanteman di Universitas John Hopkins (Arends, 2008). Teknik mengajar Jigsaw 
dikembangkan oleh Aronson et. al. sebagai metode Cooperative Learning. Teknik ini dapat digunakan dalam pengajaran membaca, menulis, mendengarkan, ataupun berbicara.

Dalam teknik ini, guru memperhatikan skemata atau latar belakang pengalaman siswa dan membantu siswa mengaktifkan skemata ini agar bahan pelajaran menjadi lebih bermakna. Selain itu, siswa bekerja sama dengan sesama siswa dalam suasana gotong-royong dan mempunyai banyak kesempatan untuk mengolah informasi dan meningkatkan keterampilan berkomunikasi.

Pembelajaran kooperatif tipe Jigsaw adalah suatu tipe pembelajaran kooperatif yang terdiri dari beberapa anggota dalam satu kelompok yang bertanggung jawab atas penguasaan bagian materi belajar dan mampu mengajarkan materi tersebut kepada anggota lain dalam kelompoknya (Arends, 2008). Model pembelajaran kooperatif tipe Jigsaw merupakan model pembelajaran kooperatif dimana siswa belajar dalam kelompok kecil yang terdiri dari 4-6 orang secara heterogen dan bekerja sama saling ketergantungan yang positif dan bertanggung jawab atas ketuntasan bagian materi pelajaran yang harus dipelajari dan menyampaikan materi tersebut kepada anggota kelompok yang lain (Arends, 2008).

Jigsaw didesain untuk meningkatkan rasa tanggung jawab siswa terhadap pembelajarannya sendiri dan juga pembelajaran orang lain. Siswa tidak hanya mempelajari materi yang diberikan, tetapi mereka juga harus siap memberikan dan mengajarkan materi tersebut pada anggota kelompoknya yang lain. Dengan demikian, "siswa saling tergantung satu dengan yang lain dan harus bekerja sama secara kooperatif untuk mempelajari materi yang ditugaskan” (Lie, A., 2002).

Para anggota dari tim-tim yang berbeda dengan topik yang sama bertemu untuk diskusi (tim ahli) saling membantu satu sama lain tentang topik pembelajaran yang ditugaskan kepada mereka. Kemudian siswa-siswa itu kembali pada tim / kelompok asal untuk menjelaskan kepada anggota kelompok yang lain tentang apa yang telah mereka pelajari sebelumnya pada pertemuan tim ahli.

Pada model pembelajaran kooperatif tipe Jigsaw, terdapat kelompok asal dan kelompok ahli. Kelompok asal yaitu kelompok induk siswa yang beranggotakan 
siswa dengan kemampuan, asal, dan latar belakang keluarga yang beragam. Kelompok asal merupakan gabungan dari beberapa ahli. Kelompok ahli yaitu kelompok siswa yang terdiri dari anggota kelompok asal yang berbeda yang ditugaskan untuk mempelajari dan mendalami topik tertentu dan menyelesaikan tugas-tugas yang berhubungan dengan topiknya untuk kemudian dijelaskan kepada anggota kelompok asal.

Hubungan antara kelompok asal dan kelompok ahli digambarkan sebagai berikut (Arends, 2008) :

Kelompok Asal

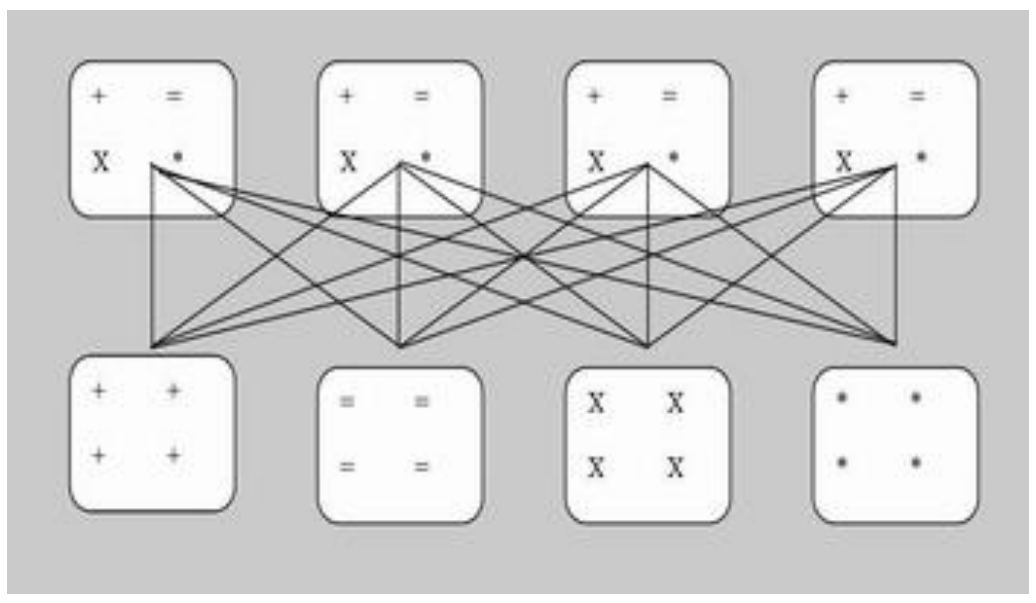

Kelompok Ahli

Gambar 1. Ilustrasi Kelompok Jigsaw

Setiap guru tentunya menginginkan pada saat proses belajar mengajar terjadi suatu interaksi yang menyenangkan antara guru dan siswa maupun antar sesama siswa. Hal ini menunjukkan bahwa dalam proses belajar mengajar dikelas siswa lebih aktif dan lebih bersemangat. Dengan kondisi tersebut guru akan lebih mudah dalam menyampaikan materi pelajaran karena pada siswa akan merespon dan memahami dengan baik. Prestasi belajar bahasa jawa pun dapat mengalami peningkatan.

Untuk meningkatkan kemampuan berfikir yang konsentrasi sehingga prestasi belajar bahasa jawa dapat meningkat, perlu adanya variasi dalam proses belajarnya. Adanya variasi pembelajaran agar siswa bisa lebih aktif dalam proses kegiatan 
belajar mengajar didalam kelas. Model pembelajaran yang bervariasi tersebut artinya dalam penggunaan model mengajar tidak harus selalu sama untuk setiap pokok bahasan karena bisa saja terjadi bahwa suatu model tertentu cocok untuk satu pokok bahasan namun tidak cocok untuk pokok bahasan yang lain.

Menurut Winkel (2007), prestasi belajar adalah bukti keberhasilan yang dicapai. Sedangkan menurut Peter Salim dalam Negoro (2008:5), prestasi belajar adalah penguasaan pengetahuan keterampilan terhadap mata pelajaran yang dibuktikan melalui hasil tes. Jadi prestasi belajar adalah bukti keberhasilan yang maksimal dan dapat dibuktikan melalui hasil tes yang diberikan guru.

Pengukuran prestasi belajar biasanya diwujudkan dalam bentuk angka atau huruf. Pengukuran ini dapat dijadikan informasi bagi pihak-pihak yang berkepentingan (siswa, guru, orang tua, dll). Dengan evaluasi dapat diketahui tingkat keberhasilan siswa sesuai dengan tujuan yang telah ditetapkan.

Menurut Sudjana (2006), faktor yang mempengaruhi prestasi belajar dibedakan menjadi tiga faktor yaitu faktor anak/ individu, faktor lingkungan dan faktor bahan atau materi yang dipelajari. Lingkungan sekolah yang memiliki unsurunsur seperti: guru, metode pengajaran, kurikulum, teman sekolah, peraturan sekolah dan sarana - prasarana sangat mempengaruhi prestasibelajar.

Berdasarkan uraian di atas, dapat dirumuskan permasalahan sebagai berikut: “Apakah model pembelajaran kooperatif tipe jigsaw dapat meningkatkan prestasi belajar bahasa Jawa siswa kelas VIII I semester I SMP Negeri 2 Sukoharjo tahun pelajaran 2016 / 2016?". Tujuan penelitian ini adalah untuk meningkatkan prestasi belajar bahasa Jawa dengan menerapkan pembelajaran kooperatif tipe jigsaw pada siswa kelas VIII I semester I SMP Negeri 2 Sukoharjo tahun pelajaran 2015 / 2016.

\section{METODE PENELITIAN}

Penelitian ini adalah Penelitian Tindakan Kelas (PTK), atau disebut juga Classroom Action Research (CAR). PTK merupakan suatu pencermatan terhadap 
kegiatan yang sengaja dimunculkan, dan terjadi dalam sebuah kelas (Arikunto, 2010: 130). Penelitian ini dilaksanakan di SMP Negeri 2 Sukoharjo. Tahap-tahap pelaksanaan kegiatan dilakukan selama kurang lebih enam bulan yaitu bulan Juli sampai dengan Desember 2016. Subjek penelitian ini, 1) siswa, yakni subjek yang dikenai tindakan. Sasaran penelitian tindakan kelas ini adalah siswa kelas VIII I SMP Negeri 2 Sukoharjo tahun pelajaran 2016/ 2017 yang berjumlah sebanyak 32 siswa, 2) Guru sebagai subjek yang melalukan tindakan, 3) Teman sejawat sesama guru mata pelajaran bahasa Jawa sebagai observer, dan 4) Kepala sekolah sebagai sumber data. Sedangkan objek penelitian ini adalah penerapan model pembelajaran kooperatif tipe jigsaw.

Pada siklus pertama planning diawali dari perencanaan pada RPP yaitu rencana apersepsi, rencana pelaksanaan kegiatan inti dan rencana pelaksanaan penutup. Pada acting peneliti melaksanakan apersepsi, kegiatan inti dan kegiatan penutup pada pembelajaran. Kegiatan selanjutnya observing, yaitu peneliti bersama observer mengamati mengambil data prestasi belajar yang didokumentasikan. Setelah data terkumpul dilakukuan kegiatan reflekting. Yaitu refleksi tentang proses pembelajaran dan hasil observasi tentang aktivitas belajar siswa. Hal ini juga dilakukan pada siklus yang ke 2. Indikator keberhasilan dalam penelitian ini adalah apabila nilai rata-rata tes siswa sekurang-kurangnya 80,0 dan banyak siswa dengan nilai di atas batas ketuntasan minimal (KKM) yaitu $\geq 75,0$ mencapai $\geq 90 \%$.

\section{HASIL DAN PEMBAHASAN}

\section{a. Hasil Penelitian}

Kondisi awal dapat diketahui dengan melakukan kegiatan observasi di kelas VIII I SMP Negeri 2 Sukoharjo. Kegiatan observasi awal ini dilakukan untuk mengetahui keadaan sebenarnya pada proses pembelajaran bahasa Jawa yang ada di lapangan. Berdasarkan observasi awal dengan teman sejawat diketahui bahwa siswa kelas VIII I memiliki prestasi belajar rendah yang disebabkan karena kurangnya perhatian dan keaktifan dari siswa saat pembelajaran dengan model ceramah. 
Berdasarkan hasil pretest materi, dari 32 siswa yang mencapai nilai kriteria ketuntasan minimal (KKM) yaitu 75 sebanyak 12 siswa (37,5\%) dan siswa yang tidak mencapai nilai kriteria ketuntasan minimal (KKM) sebanyak 20 siswa $(62,5 \%)$ dengan nilai rata-rata kelas sebesar 68,9. Guru hanya menerapkan model ceramah dan siswa hanya disuruh mendengarkan dan mencatat apa yang diperlukan. Hasil ini dapat ditampilkan pada grafik berikut.

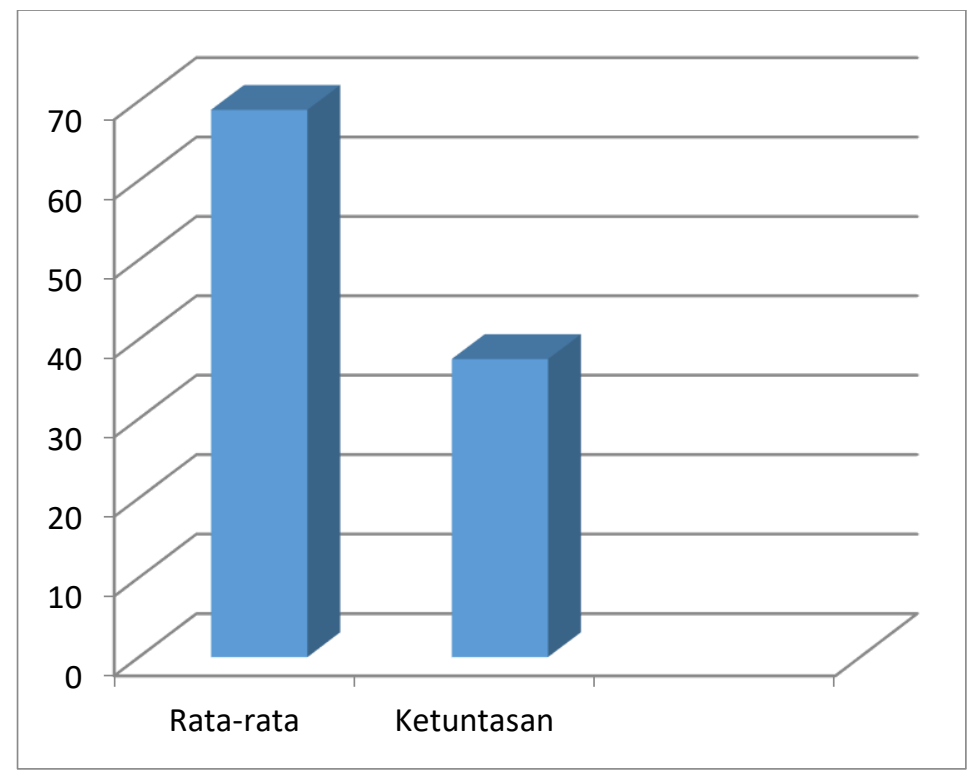

\section{Gambar 2. Grafik Prestasi Belajar Bahasa Jawa Siswa pada Prasiklus}

Salah satu solusi yang dikembangkan adalah penggunaan model pembelajaran kooperatif tipe jigsaw. Dengan penggunaan model pembelajaran tersebut diharapkan akan menciptakan suasana belajar yang berbeda, bervariasi dan menyenangkan sehingga dapat menarik perhatian siswa dan meningkatkan prestasi belajar siswa.

\section{1) Tindakan Siklus I}

Pembelajaran dilaksanakan dengan pedoman Rencana Perbaikan Pembelajaran (RPP) selama 4 jam pelajaran (4 x 40 menit). Kompetensi Dasar yang disampaikan pada siklus I adalah menulis surat undangan. Model pembelajaran tipe jigsaw dilaksanakan dengan menggunakan langkah-langkah sebagai berikut: (1) Pendahuluan berisi kegiatan guru memberi salam, mengkondisikan kelas, dan mengecek presensi siswa. Guru menyampaikan tujuan pembelajaran yang ingin 
dicapai dan memberi motivasi belajar; (2) Kegiatan inti tentang pelaksanaan kegiatan model pembelajaran kooperatif tipe jigsaw digunakan dari awal memberikan materi dan memberikan latihan kepada siswa, adapun langkahlangkah kegiatannya sebagai berikut: (a) guru membagi siswa menjadi 5 kelompok, tiap kelompok beranggotakan 6-7 siswa, yang heterogen; (b) Terdapat kelompok asal dan kelompok ahli. Kelompok asal yaitu kelompok induk siswa yang beranggotakan siswa dengan kemampuan, asal, dan latar belakang keluarga yang beragam. Kelompok asal merupakan gabungan dari beberapa ahli. Kelompok ahli yaitu kelompok siswa yang terdiri dari anggota kelompok asal yang berbeda yang ditugaskan untuk mempelajari dan mendalami topik tertentu dan menyelesaikan tugas-tugas yang berhubungan dengan topiknya untuk kemudian dijelaskan kepada anggota kelompok asal; (c) siswa mempresentasikan kasil kerja kelompok; (d) siswa mengkritisi presentasi kelompok lain; dan (e) guru bersama siswa memberi penguat. (3) Penutup, berisi kegiatan guru memberikan kesempatan siswa untuk menanyakan hal-hal yang kurang jelas. Kemudian guru memberikan postest, dan memberikan tugas rumah.

Dalam tahap pengamatan tindakan ini, ternyata masih banyak siswa yang kurang aktif dan masing kurang bisa beradaptasi dengan model pembelajaran yang baru. Semuanya dapat dilihat pada saat pelaksanaan pembelajaran dengan menggunakan model pembelajaran kooperatif tipe jigsaw. Siswa yang kurang aktif cenderung hanya mengikuti arahan dari guru.

Hasil observasi menunjukkan bahwa guru telah melaksanakan kegiatan pembelajaran dengan cukup baik, yaitu guru mengajar dengan arah dan tujuan yang jelas. Namun ketika guru menyampaikan materi dengan model pembelajaran kooperatif tipe jigsaw, beberapa siswa tampak masih kurang memperhatikan, dan beraktivitas sendiri. Selain itu tidak semua kelompok dapat berdiskusi dengan baik.

Setelah guru melaksanakan pembelajaran bahasa Jawa dengan model pembelajaran kooperatif tipe jigsaw, guru melaksanakan evaluasi kepada siswa untuk mengetahui prestasi belajar siswa dalam mempelajari materi. Berdasarkan hasil evaluasi pada siklus I menunjukkan adanya peningkatan prestasi belajar siswa. Rata-rata prestasi belajar siswa pada siklus I adalah 73,6, sebanyak 20 siswa 
$(62,5 \%)$ mencapai nilai kriteria ketuntasan minimal (KKM), dan sebanyak 12 siswa $(37,5 \%)$ tidak mencapai nilai kriteria ketuntasan minimal (KKM). Berdasarkan hasil tersebut dapat diketahui bahwa proses pembelajaran pada siklus pertama sudah meningkatkan prestasi belajar tetapi belum berjalan dengan cukup baik serta belum mencapai indikator kinerja yang diharapkan. Hasil ini dapat ditampilkan pada grafik berikut.

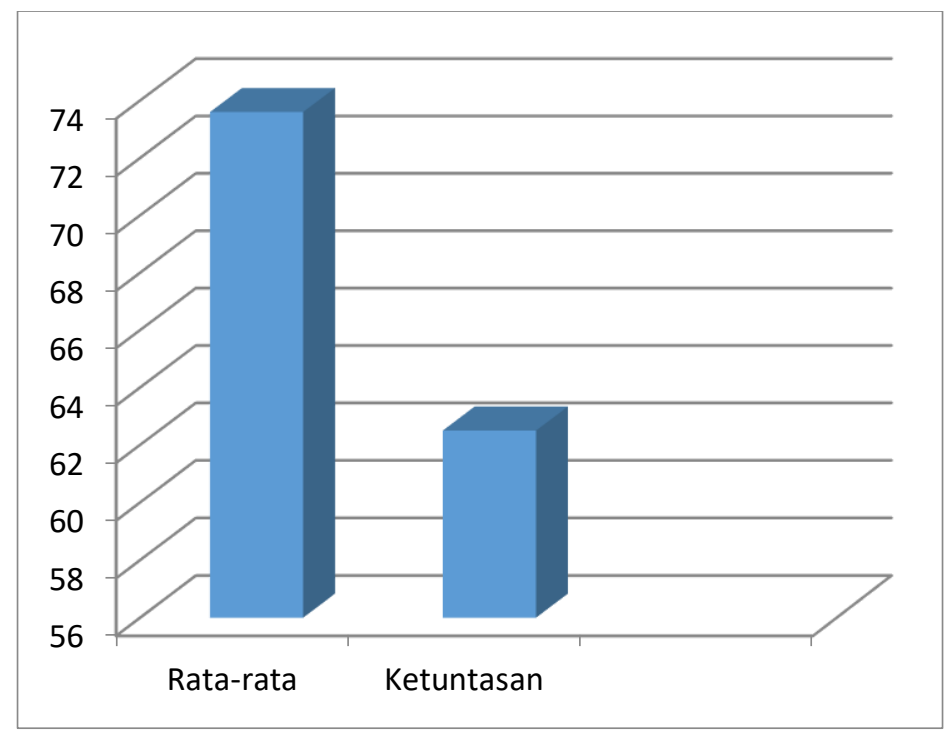

\section{Gambar 3. Grafik Prestasi Belajar bahasa Jawa Siswa pada Siklus I}

Keberhasilan yang dicapai setelah siklus I hanya sebagian siswa yang menunjukkan partisipasi yang meningkat sementara siswa lainnya masih pasif. Refleksi terhadap faktor-faktor yang menjadi penyebab kurangnya partisipasi siswa adalah: (1) Sebagian siswa belum bisa mengikuti langkah-langkah pembelajaran model pembelajaran kooperatif tipe jigsaw; (2) Kerjasama dalam kelompok berdiskusi belum maksimal; (3) Hanya siswa tertentu saja yang dapat memahami materi dan soal yang diberikan kepada setiap kelompok.

Solusi yang diambil untuk mengatasi permasalahan tersebut adalah perlu dilakukan tindakan berikutnya untuk meningkatkan perhatian dan keaktifan belajar siswa dengan meningkatkan antusias siswa untuk mengikuti pembelajaran dengan model pembelajaran kooperatif tipe jigsaw, guru memantau siswa pada saat pemberian materi sehingga guru dapat menegur siswa yang kurang memperhatikan 
dan mendorong keberanian siswa dalam mengungkapkan pendapat ketika siswa belum mengerti tentang materi yang disampaikan oleh guru.

\section{2) Tindakan Siklus II}

Model pembelajaran tipe jigsaw dilaksanakan dengan menggunakan langkah-langkah sebagai berikut: (1) Pendahuluan berisi kegiatan guru memberi salam, mengkondisikan kelas, dan mengecek presensi siswa. Guru menyampaikan tujuan pembelajaran yang ingin dicapai dan memberi motivasi belajar; (2) Kegiatan inti tentang pelaksanaan kegiatan model pembelajaran kooperatif tipe jigsaw digunakan dari awal memberikan materi dan memberikan latihan kepada siswa, adapun langkah-langkah kegiatannya sebagai berikut: (a) guru membagi siswa menjadi 8 kelompok, tiap kelompok beranggotakan 4 siswa, yang heterogen; (b) Terdapat kelompok asal dan kelompok ahli. Kelompok asal yaitu kelompok induk siswa yang beranggotakan siswa dengan kemampuan, asal, dan latar belakang keluarga yang beragam. Kelompok asal merupakan gabungan dari beberapa ahli. Kelompok ahli yaitu kelompok siswa yang terdiri dari anggota kelompok asal yang berbeda yang ditugaskan untuk mempelajari dan mendalami topik tertentu dan menyelesaikan tugas-tugas yang berhubungan dengan topiknya untuk kemudian dijelaskan kepada anggota kelompok asal; (c) siswa mempresentasikan kasil kerja kelompok; (d) siswa mengkritisi presentasi kelompok lain; dan (e) guru bersama siswa memberi penguat. (3) Penutup, berisi kegiatan guru memberikan kesempatan siswa untuk menanyakan hal-hal yang kurang jelas. Kemudian guru memberikan postest, dan memberikan tugas rumah.

Berdasarkan kegiatan observasi, secara garis besar diperoleh gambaran pelaksanaan tindakan siklus II ada peningkatan prestasi belajar siswa. Dalam pertemuan ini banyak siswa mampu menjawab soal-soal yang diberikan dengan benar dan baik. Sebagian siswa aktif dalam bertanya dan mengemukakan ide mereka. Siswa juga dapat memahami materi yang telah diajarkan hal ini terlihat dari cara siswa menyelesaikan soal-soal.

Setelah guru melaksanakan pembelajaran bahasa jawa dengan model pembelajaran kooperatif tipe jigsaw, guru melaksanakan evaluasi kepada siswa untuk mengetahui prestasi belajar siswa dalam mempelajari materi menanggapi 
surat undangan. Berdasarkan hasil evaluasi pada siklus II menunjukkan adanya peningkatan prestasi belajar siswa. Rata-rata prestasi belajar siswa pada siklus II adalah 81,6 sebanyak 30 siswa (93,75\%) mencapai nilai kriteria ketuntasan minimal (KKM), dan sebanyak 2 siswa $(6,25 \%)$ tidak mencapai nilai kriteria ketuntasan minimal (KKM). Hasil ini dapat ditampilkan pada grafik berikut.

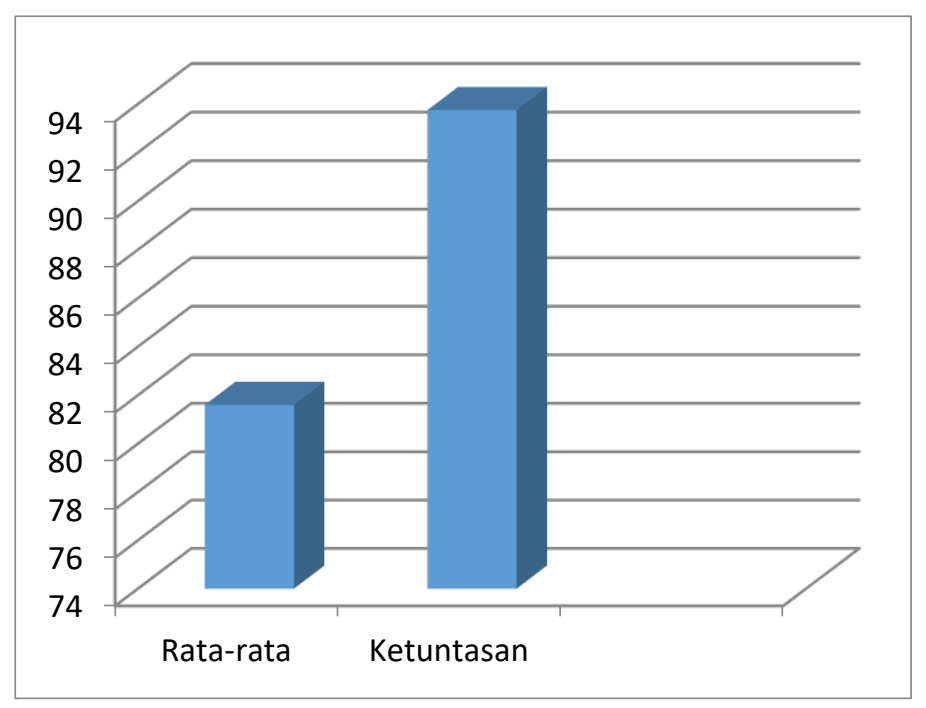

\section{Gambar 4. Grafik Prestasi Belajar bahasa JawaSiswa pada Siklus II}

Sebagian siswa menunjukkan partisipasinya meningkat dari siklus I. Keberhasilan yang dicapai setelah siklus II telah memenuhi indikator keberhasilan penelitian ini, sehingga tindakan ini tidak diteruskan atau dihentikan pada siklus II.

Berdasarkan pengolahan dan analisis data di atas, maka diperoleh interpretasi bahwa penerapan model pembelajaran kooperatif tipe jigsaw terhadap peningkatan prestasi belajar siswa menunjukkan bahwa terjadi peningkatan prestasi belajar siswa pada sebelum tindakan siklus I, dan pada siklus I ke siklus II. Terjadi peningkatan prestasi belajar siswa ini sebagai efek dari meningkatkan keterampilan sosial dan kemandirian siswa yaitu adanya perhatiaan siswa dalam proses belajar, kerjasama dalam tiap pasangan kelompok dan kemandirian dalam mengerjakan soal. 
Hal ini dapat dilihat dari hasil penelitian dari siklus pertama sampai dengan siklus ketiga dapat diringkaskan seperti terlihat pada tabel sebagai berikut:

Tabel 1. Profil Kelas Sebelum dan Sesudah Tindakan Penelitian

\begin{tabular}{lllll}
\hline No & \multicolumn{1}{c}{ Hasil Siswa } & Kondisi Awal & Siklus I & Siklus II \\
\hline 1 & Nilai rata-rata & 68,9 & 73,6 & 81,6 \\
\hline 2 & Siswa yang tunt: & 12 siswa & 20 siswa & 30 siswa \\
& Persentase Ketuntasan & $(37,5 \%)$ & $(62,5 \%)$ & $(93,75 \%)$
\end{tabular}

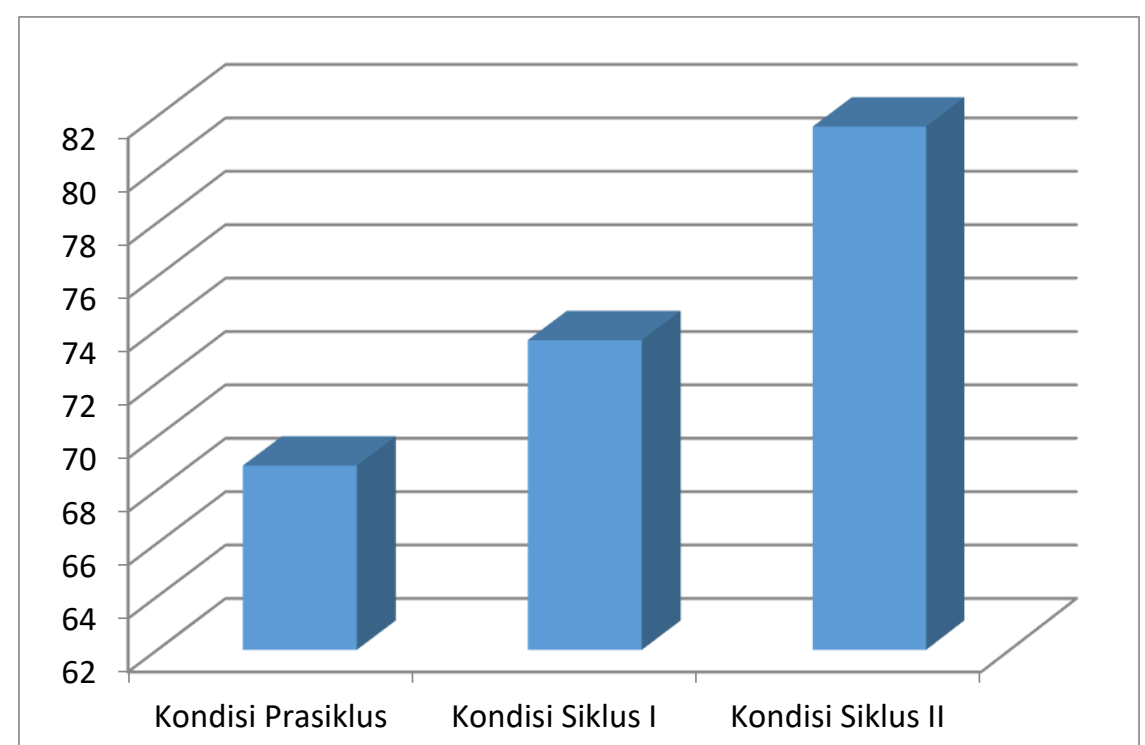

Gambar 5. Grafik Hasil Peningkatan Rata-Rata Prestasi Belajar bahasa Jawa

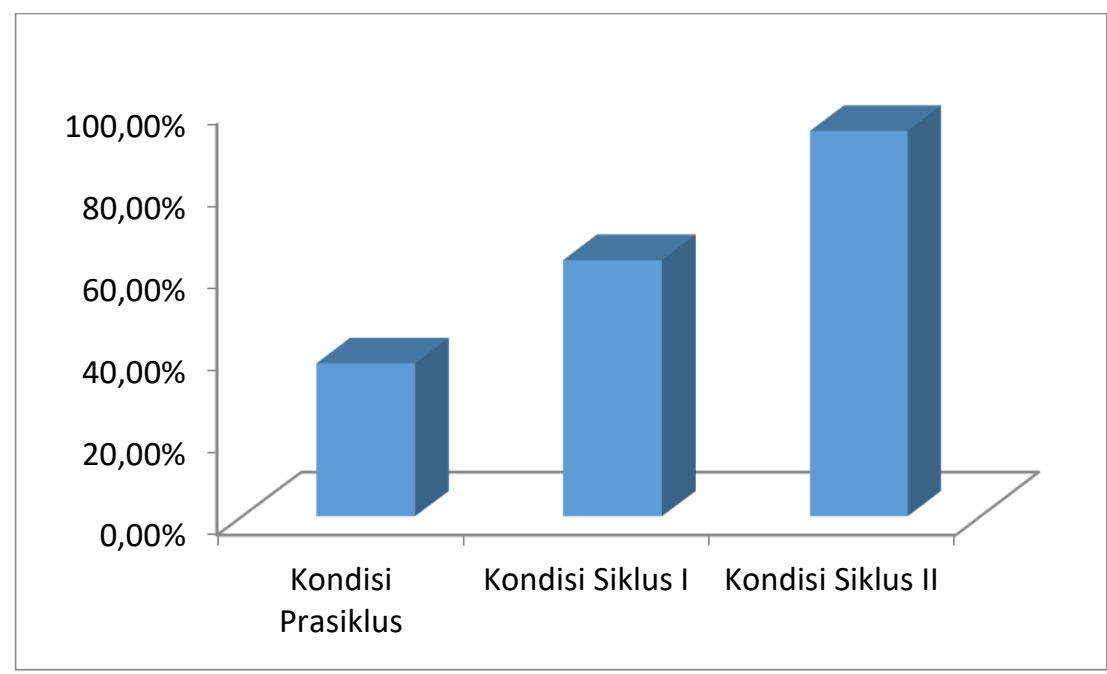




\section{Gambar 6. Grafik Hasil Peningkatan Ketuntasan Prestasi Belajar Bahasa Jawa}

Dari tabel 1, grafik 5 dan 6 di atas dapat disimpulkan bahwa prestasi belajar bahasa Jawa siswa dengan menerapkan model pembelajaran kooperatif tipe jigsaw di setiap putaran mengalami peningkatan, yaitu: (1) Sebelum dilakukan tindakan, nilai rata-rata prestasi belajar siswa adalah 68,9 sedangkan persentase ketuntasan 37,5\%; (2) Setelah dilakukan tindakan pada siklus I, nilai rata-rata prestasi belajar bahasa Jawa siswa mengalami peningkatan yaitu 73,6 dengan persentase ketuntasan $62,5 \%$, tetapi belum mencapai indikator yang diharapkan; (3) Pada siklus II, nilai prestasi belajar siswa meningkat yaitu menjadi 81,6 dengan persentase ketuntasan sebesar 93,75\% dan sudah mencapai indikator yang diharapkan maka penelitian tindakan kelas ini sudah berhasil.

Rata-rata prestasi belajar bahasa Jawa siswa pada siklus II sebesar $81,6 \geq$ 80,0 (indikator kinerja) dan persentase ketuntasan siklus II sebesar 93,75\% $\geq 90 \%$ (indikator kinerja). Jadi, indikator kinerja sudah tercapai sehingga tidak dilanjutkan ke siklus berikutnya.

\section{SIMPULAN}

Penggunaan model pembelajaran kooperatif tipe jigsaw dapat meningkatkan prestasi belajar bahasa Jawa siswa kelas VIII I semester I SMP Negeri 2 Sukoharjo tahun pelajaran 2016/2017. Hasil penelitian ini menunjukkan adanya peningkatan pada prestasi belajar bahasa Jawa siswa. Hal ini dapat dilihat dari nilai rata-rata prestasi belajar bahasa Jawa siswa juga mengalami peningkatan yaitu sebelum tindakan sebesar 61,6, pada siklus I sebesar 73,6 dan pada siklus II sebesar 81,6. Selain itu, persentase ketuntasan belajar siswa, yaitu sebelum tindakan sebesar $37,5 \%$, pada siklus I sebesar $62,5 \%$ dan pada siklus II sebesar 93,75\%.

\section{DAFTAR PUSTAKA}

Arends, Richard I. 2008. Learning To Teaching. Yogyakarta : Pustaka Pelajar Aqib, Zainal. 2009. Penelitian Tindakan Kelas. Jakarta: Yrama Widia. 
Arikunto, Suharsimi. 2009. Dasar-Dasar Evaluasi Pendidikan. Jakarta : Bumi Aksara.

Basleman, Anisah dkk. 2011. Teori Belajar. Bandung: PT Remaja Rosdakarya,

Budiono, Santoso. 2008. Pembelajaran Cooperatif Tipe Jigsaw dapat Meningkatkan Keefektifan Proses Belajar Mengajar Fisika Di SMP N 5 Karanganyar.

Dimiyati dan Mudjiono. 2006. Belajar dan Pembelajaran. Jakarta : Rineka Cipta.

Isjoni. 2009. Cooperative Learning. Bandung : Alfabeta

Lie, Anita. 2002. Mempraktekkan Cooperative Learning Diruang-ruang Kelas. Jakarta: Grasindo.

Purwanto, M. Ngalim 2009. Pinsip-Prinsip dan Teknik Evaluasi Pengajaran. Bandung : PT. Remaja Jaya.

Robert Bogdandan Steven J. Taylor, 1993. Kualitatif Dasar-dasar Penelitian, Surabaya: Usaha Nasional.

Rusman, 2010. Model-Model Pembelajaran. Bandung : Rajawali Press.

Slavin. 1985. Cooperative Learning Theory. Second Edition. Massachusetts : Allyn and Bacon Publisher.

Sujdana, Nana. 2006. Penilaian Hasil Proses Belajar Mengajar. Bandung: PT Rosdakarya.

Winkel. W.S. 1997. Psikologi Pengajaran. Jakarta : Gramedia 